\title{
Pi Sigma Alpha Announces Award Winners
}

\section{HOWARD PENNIMAN \\ SCHOLARSHIPS FOR GRADUATE STUDY}

Four outstanding young scholars were awarded Howard Penniman Scholarships for Graduate Study in 2015. The \$200o scholarships are awarded annually to undergraduate student members entering graduate school in political science.

Andew Podob, University of Maryland $\mathrm{PhD}$ program in political science at Ohio State University

Jamel Love, CUNY-John Jay College $\mathrm{PhD}$ program in political science at Rutgers University

Elizabeth McGuire, Brigham Young University

PhD program in political science at Yale University

C. James Peranteau, University of Wisconsin, Milwaukee

MS program, School of Foreign Service at Georgetown University

\section{Penniman Scholarship Selection Committee:}

Chair: Chuck Finocchiaro, University of South Carolina; James Campbell, SUNY, Buffalo; and Kerstin Hamann, University of Central Florida

\section{NANCY MCMANUS WASHINGTON INTERN SCHOLARSHIPS}

Six talented Pi Sigma Alpha members were awarded Nancy McManus Washington Intern Scholarships in 2015. The \$200o scholarships are awarded annually to undergraduate student members who spend a summer or semester serving as an intern in Washington, DC.

Molly Lawrence, Temple University: Urban Institute, DC Tutoring and Mentoring Initiative, Summer 2015

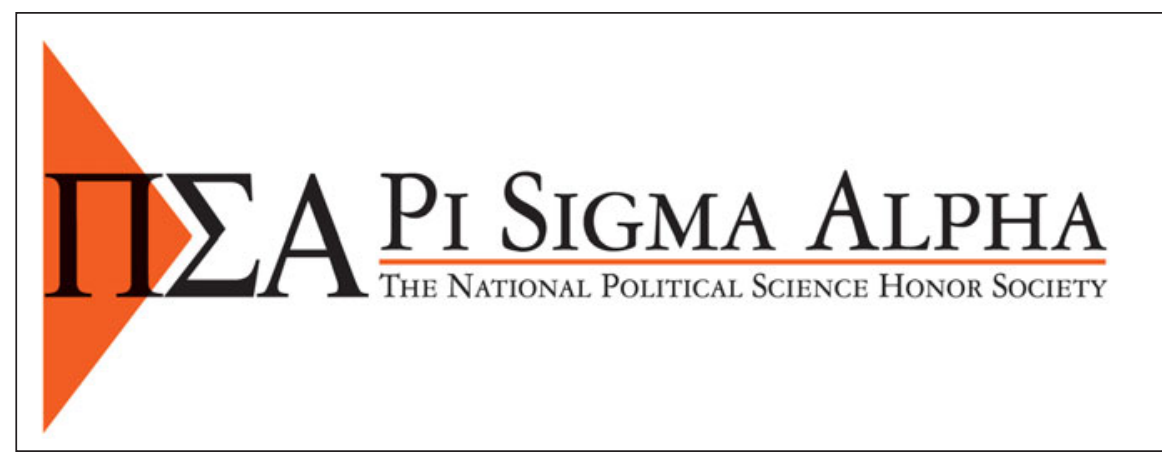

Laura Rose Donegan, University of New Hampshire: Torture Abolition and Survivors Support Coalition, Summer 2015

Catherine Simons, Oakland University: National Association of Schools of Public Administration and Affairs Summer 2015

Elizabeth Rilling, Adelphi University: Washington Center Internship Fall 2015

Briana Bills, University of South Carolina: University of South Carolina Washington Semester Program, Fall 2015

Joshua Cooper, Brigham Young University: Office of Senator Mike Lee, Fall 2015

\section{PI SIGMA ALPHA BEST CHAPTER AWARDS}

Pi Sigma Alpha annually recognizes those chapters that have excelled in the past year. The selection is based on chapter annual reports to the National Office, and other evidence of extraordinary levels of activity. Winners in four categories for 2015 are:

\section{Under 5,00o Enrollment:}

Providence College

Tony Affigne, chapter advisor

Valparaiso University

Jennifer Hora, chapter advisor

Lee University

Thomas Pope and Ana Alves, chapter advisors
Union College

Guillermina Seri, chapter advisor

5,000-14,999 Enrollment:

California State University, East Bay

Kim Geron, chapter advisor

University of Pennsylvania

Eileen Doherty-Sil, chapter advisor

Missouri Western State University Edwin Taylor, chapter advisor

15,000-24,999 Enrollment:

California State University,

San Bernardino

Brian Janiskee, chapter advisor

Oakland University

Terri Towner, chapter advisor

University of Wisconsin, Milwaukee Kristin Trenholm, chapter advisor

Over 25,00o Enrollment:

Brigham Young University

David Magleby, chapter advisor

California State University, Fullerton Valerie O'Regan, chapter advisor

University of Maryland Kathryn Weiland, chapter advisor

Pennsylvania State University Amy Linch, chapter advisor 